\title{
Adhesive bonding of beech wood modified with a phenol formaldehyde compound
}

\author{
Stergios Adamopoulos • Alireza Bastani • \\ Patricia Gascón-Garrido • Holger Militz • \\ Carsten Mai
}

Received: 7 December 2011/Published online: 5 June 2012

(C) The Author(s) 2012. This article is published with open access at Springerlink.com

\begin{abstract}
Untreated (controls) and phenol-formaldehyde (PF)-modified beech wood (10 and $25 \%$ solid content) were glued with phenol resorcinol formaldehyde (PRF) and polyvinyl acetate (PVAc). Shear strength of PRF-bonded specimens was higher than that of PVAc-bonded ones under dry and wet conditions irrespective of the pre-treatment. Under dry conditions, only PVAc-bonded specimens exhibited reduction in shear strength due to PF-modification with $25 \% \mathrm{PF}$ concentration as compared to the controls. PF treated wood provided inferior bonding under wet conditions with the exception of $25 \% \mathrm{PF}$ concentration specimens glued with PRF adhesive. Modification with PF resulted in a decrease of adhesive penetration into the porous network of interconnected cells, especially at $25 \%$ PF concentration.
\end{abstract}

\section{Verklebung von mit einer Phenol-Formaldehyd- Verbindung modifiziertem Buchenholz}

\section{Introduction}

Wood modification is a well-established technology to improve biological durability, dimensional stability,

S. Adamopoulos · A. Bastani · P. Gascón-Garrido · H. Militz ·

C. Mai $(\square)$

Wood Biology and Wood Products, Burckhardt Institute,

Georg-August-University Göttingen, Büsgenweg 4,

37077 Göttingen, Germany

e-mail: cmai@gwdg.de

S. Adamopoulos

Department of Forestry and Management of Natural

Environment, Technological Educational Institute

of Larissa, 43100 Karditsa, Greece hardness and weathering resistance of wood (Hill 2006). Besides these advantages, modification can alter the adhesive strength due to changes in chemical, physical and structural properties of wood. The less polar and less porous modified wood surfaces may lead to reduced adhesion due to poorer adhesive wetting of the wood and fewer chemical bonds between the two surfaces (Hunt et al. 2007). On the other hand, improved bonding performance can be achieved as the improved dimensional stability of modified wood results in less shrinking and swelling stresses on the cured adhesive bond (Sernek et al. 2008).

The great variety of wood adhesives, species, and modification methods (chemical, thermal) makes the bonding behaviour of modified wood a complex subject. Acetylation of wood has been shown to affect bonding strength depending on the type of adhesive (Vick and Rowell 1990; Vick et al. 1993; Frihart et al. 2004). The additional hydroxyl groups being available for hydrogenbonding with the adhesive provided by oxide modifications with butylene and propylene oxide did not give superior adhesion over wood that was acetylated (Brandon et al. 2005). Furfurylated wood could be glued satisfactorily with two different gluing systems even though the percentage glue line failure increased under wet conditions (van der Zee et al. 2007). The poor bonding properties of silicone modified wood were improved by using hydroxymethylated resorcinol as a coupling agent (Kurt et al. 2008). Heat treatment of wood was also reported to affect the glueability of wood in several ways depending on the adhesive type used (Boonstra et al. 1998; Sernek et al. 2008; Sahin Kol et al. 2009).

Impregnation of wood with water soluble, low molecular weight phenol-formaldehyde (PF) resin systems has been researched since the 1930s with main purpose to increase the dimensional stability of solid wood as well as 
of the commercial plywood composites Impreg and Compreg (Stamm 1959; Hill 2006; Gabrielli and Kamke 2010). Phenol-formaldehyde resins were shown to penetrate and bulk the cell wall (Stamm and Seborg 1936; Rowell and Banks 1985). Ohmae et al. (2002) obtained anti-shrink efficiencies (ASE) up to 74 at $30 \%$ weight percent gain (WPG) using a low molecular weight PF due to both bulking and cross-linking of the cell wall. PF modification has also been shown to enhance the resistance against white rot and brown rot fungi (Ryu et al. 1991). The effectiveness of modification was shown to depend on the penetration of phenol formaldehyde resins into wood cell walls (Ryu et al. 1993; Furuno et al. 2004).

With new modification processes becoming commercially available and increasing use of modified wood for exterior and interior applications, it is important to continuously update our knowledge on adhesive bonding of modified wood. PF modification has a good chance of commercialisation due to the enhanced wood properties, the relatively low price of PF resin and the relatively easy feasibility of the process. The aim of this study was to evaluate the bonding performance of phenol formaldehyde modified wood glued with two adhesive systems, phenol resorcinol formaldehyde and polyvinyl acetate. The tensile shear bond strength and penetration of adhesives into the porous wood structure were examined.

\section{Materials and methods}

\subsection{Treatment}

Defect-free assembly wood blocks of beech (Fagus sylvatica L.) with dimensions 600 (longitudinal) $\times 130 \times$ $6 \mathrm{~mm}^{3}$ and average density of $680 \mathrm{~kg} \mathrm{~m}^{-3}$ at $12 \%$ moisture content were used for the study. The angle between the growth rings and the surface to be bonded was kept between $30^{\circ}$ and $90^{\circ}$. The wood blocks were treated with phenol formaldehyde (PF) with sodium hydroxide added in an aqueous solution with two different concentrations: 10 and $25 \%$ based on the solid content of PF. PF was provided by Cytec Surface Specialties $\mathrm{GmbH} \& \mathrm{Co}$. KG (Wiesbaden, Germany) with average molecular weight $408 \mathrm{~g} \mathrm{~mol}^{-1}$ (determined by gel permeation chromatography using polystyrene standards), specific gravity $1.15 \mathrm{~g} \mathrm{~cm}^{-3}$, viscosity $2.760 \mathrm{mPa} \mathrm{s}$ at $23{ }^{\circ} \mathrm{C}$, and $78 \%$ solid content. The treatment was conducted in a stainless steel vessel involving a vacuum (100 mbar for $1 \mathrm{~h}$ ) and a pressure phase (12 bar for $2 \mathrm{~h}$ ). The wood blocks were then cured gradually from 40 to $120{ }^{\circ} \mathrm{C}$ in an oven for a total duration of 11 days. After curing, the blocks were conditioned at $20{ }^{\circ} \mathrm{C}$ and $65 \% \mathrm{RH}$ in a climate chamber to reach equilibrium moisture content.

\subsection{Gluing}

Phenol resorcinol formaldehyde PRF (Prefere 4040 with $20 \%$ hardener; Dynea GmbH, Erkner, Germany) and polyvinyl acetate PVAc (Ponal Super 3 with $15 \%$ D4 hardener; Henkel AG \& Co., Düsseldorf, Germany) were spread uniformly on the wood blocks by hand brushing. Pressing of the assemblies was carried out for $120 \mathrm{~min}$ in a hydraulic press at room temperature and at a pressure of $1.5 \mathrm{~N} \mathrm{~mm}^{-2}$. Block shear specimens were cut from the assemblies and randomly assigned to either the dry or wet shear tests. Before testing all specimens were conditioned at $20{ }^{\circ} \mathrm{C}$ and $65 \% \mathrm{RH}$ in a climate chamber for 7 days. Specimens for the wet shear test were further soaked in water at $15 \pm 5^{\circ} \mathrm{C}$ for 4 days and tested in the wet state. The measurement of longitudinal shear strength was carried out in a Zwick/Roell Z010 universal testing machine according to the European Standard (1992) EN 302-1. Ten replicates were used for each adhesive and treatment.

\subsection{Adhesive penetration}

To observe the adhesive penetration into the porous wood structure, 20-30 $\mu \mathrm{m}$ thick sections exposing a bondline with a cross-sectional surface at various longitudinal positions of the specimens were cut on a Reichert-Jung sliding microtome. The sections were placed on glass slides, unstained for PRF bondlines and after staining with a pipette drop of $0.5 \%$ safranin $\mathrm{O}$ solution for PVAc bondlines. PVAc sections were examined under an Eclipse $50 \mathrm{i}$ fluorescence microscope with appropriate filter sets, equipped with a Sight DS-5M-L1 digital camera (both Nikon, Düsseldorf, Germany), while conventional light microscopy was applied for PRF sections by using the same microscope. Penetration depth of the adhesive was measured on 25 positions along $130 \mathrm{~mm}$ of bondline for each section.

\section{Results}

Table 1 presents tensile shear strength and wood failure data results obtained for each adhesive. Under both dry and wet condition, PRF adhesive produced higher shear strengths and wood failure percentages than PVAc irrespective of the pre-treatment. In the dry test, bonding strength remained unchanged after modification with $\mathrm{PF}$ except for the specimens modified with $25 \%$ concentration when glued with PVAc; these showed a significantly lower strength of $6.13 \mathrm{~N} \mathrm{~mm}^{-2}$ (ANOVA and Tukey HSD test, $P=5 \%$ ). This combination also gave the lowest wood failure percentage $(40 \%)$, while wood failure percentages of $80-90 \%$ for all other cases verify the 
acceptable bonds produced by the PF-treated wood under dry conditions. Under wet conditions, PVAc bonds weakened considerably giving almost zero shear strength values $\left(0.15-0.60 \mathrm{~N} \mathrm{~mm}^{-2}\right)$ for PF-modified wood and correspondingly very little wood failure $(10 \%)$. Exposure to water-soaking almost halved the bonding strength of

Table 1 Bonding strength of beech wood modified with phenol formaldehyde (PF)

Tab. 1 Klebefestigkeit von mit Phenol-Formaldehyd (PF) behandeltem Buchenholz

\begin{tabular}{|c|c|c|c|c|c|c|c|}
\hline \multirow[t]{3}{*}{ Adhesive type/PF solid content } & \multicolumn{5}{|c|}{ Tensile shear strength $\left(\mathrm{N} / \mathrm{mm}^{2}\right)$} & \multicolumn{2}{|c|}{ Mean wood failure (\%) } \\
\hline & \multicolumn{2}{|c|}{ Dry condition } & \multicolumn{2}{|c|}{ Wet condition } & \multirow[t]{2}{*}{$t$} & \multirow[t]{2}{*}{ Dry condition } & \multirow[t]{2}{*}{ Wet condition } \\
\hline & Mean & $\pm \mathrm{SD}$ & Mean & $\pm \mathrm{SD}$ & & & \\
\hline PVAc/Control & $8.79^{\mathrm{a}}$ & 3.44 & $3.73^{\mathrm{a}}$ & 1.53 & $3.880^{*}$ & 90 & 20 \\
\hline PVAc/10 \% & $8.37^{\mathrm{ab}}$ & 1.98 & $0.60^{\mathrm{b}}$ & 0.27 & $12.267 *$ & 80 & 10 \\
\hline $\mathrm{PVAc} / 25 \%$ & $6.13^{\mathrm{b}}$ & 1.31 & $0.15^{\mathrm{b}}$ & 0.08 & $10.980 *$ & 40 & 10 \\
\hline $\mathrm{F}$ & $4.273 *$ & & $36.214^{*}$ & & & & \\
\hline PRF/Control & 11.17 & 2.01 & $7.51^{\mathrm{ab}}$ & 1.25 & $4.822 *$ & 90 & 60 \\
\hline $\mathrm{PRF} / 10 \%$ & 10.23 & 2.12 & $5.97^{\mathrm{b}}$ & 1.58 & $5.040 *$ & 80 & 40 \\
\hline $\mathrm{RPF} / 25 \%$ & 9.92 & 3.01 & $8.58^{\mathrm{a}}$ & 2.02 & $1.170^{\mathrm{ns}}$ & 80 & 70 \\
\hline F & $0.686^{\mathrm{ns}}$ & & $5.933^{*}$ & & & & \\
\hline
\end{tabular}

Values followed by a different letter within a column are statistically different at $P=5 \%$ (ANOVA and Tukey HSD test)

* Differences statistically significant at $P=5 \%$

${ }^{n s}$ Differences not statistically significant
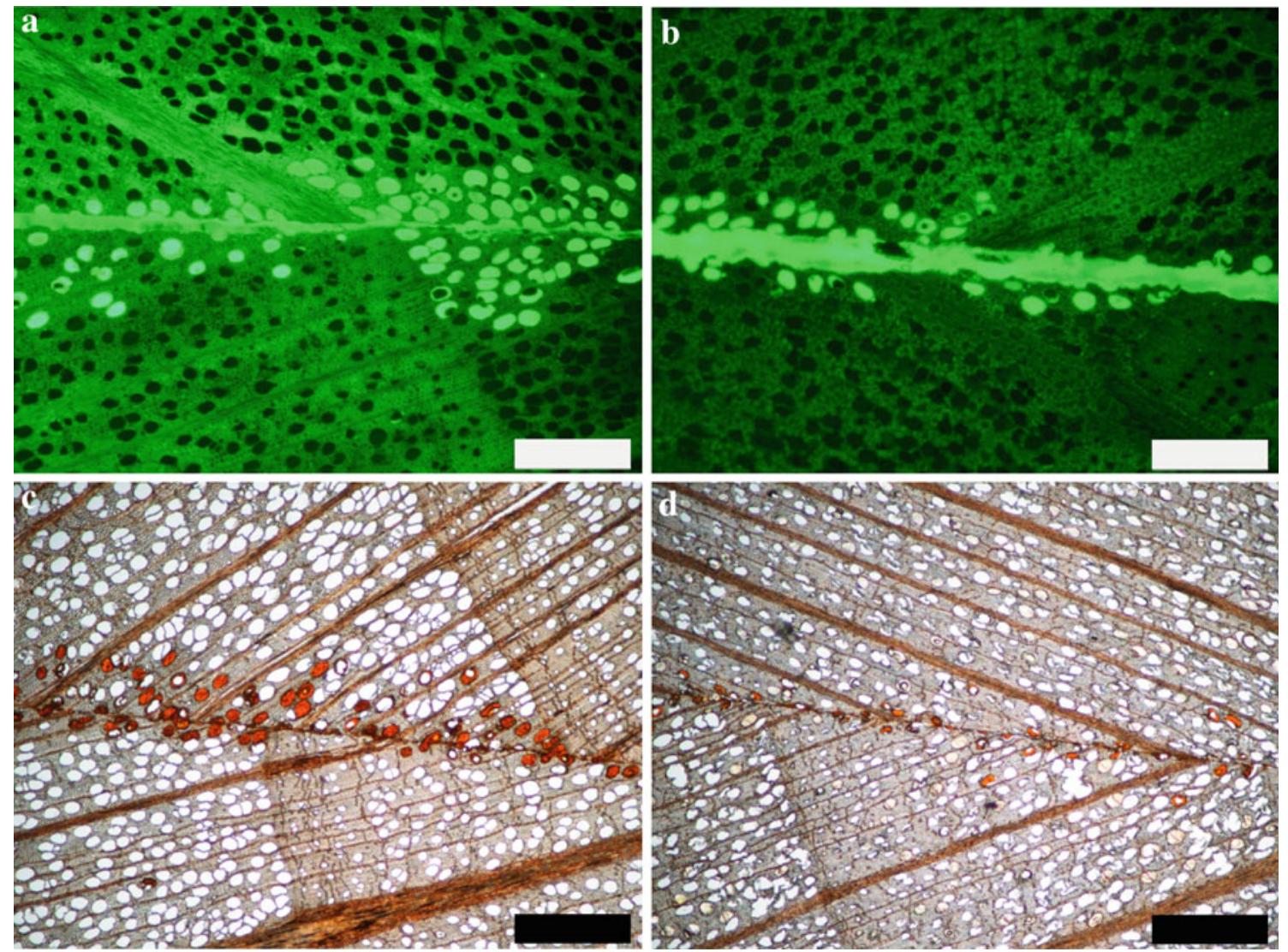

Fig. 1 Transverse view of horizontal bondlines in beech wood modified with phenol formaldehyde in $10 \%$ (a, c) and $25 \%$ concentration (b, d) using fluorescence light for PVAc (a, b) and visible light for PRF adhesive (c, d). Scale bars: $500 \mu \mathrm{m}$

Abb. 1 Querschnitt der horizontalen Klebstoffschicht von Buchenholz, das mit 10\%iger (a, c) und 25\%iger Phenol-Formaldehyd-Lösung modifiziert wurde, wobei zur Detektion von PVAc Fluoreszenzlicht $(\mathbf{a}, \mathbf{b})$ und von PRF-Klebstoff sichtbares Licht (c, d) verwendet wurde. Maßstabsskala: $500 \mu \mathrm{m}$ 
$10 \%$ PF-modified and PRF-bonded samples but had no statistically significant effect for $25 \% \mathrm{PF}$ pre-treatment ( $t$ test, $P=5 \%$ ). Differences in wood failure percentages between the dry and wet condition were in agreement with the shear strength data for the PRF adhesive. Improved adhesion with PRF adhesive in wet conditions could be obtained with increasing PF concentration. The $25 \% \mathrm{PF}$ treated samples showed higher wood failure (70\%) and strength $\left(8.58 \mathrm{~N} \mathrm{~mm}^{-2}\right)$ than the $10 \% \mathrm{PF}$ treated ones (respective values were $40 \%$ and $5.97 \mathrm{~N}$ $\mathrm{mm}^{-2}$; for shear strength, differences were statistically significant using Tukey's analysis at $P=5 \%$ ). However, shear strength of modified wood in each concentration did not differ significantly when compared to unmodified wood (ANOVA and Tukey HSD test, $P=5 \%$ ).

For all treatments and adhesive types, a discontinuous interphase (e.g. volume in which both wood cells and adhesive are present) was seen further away from the bondline (Fig. 1). Penetration was dominated by flow through the vessels and appeared either as total or partial filling of the lumens. The observations of this study did not reveal any evidence of adhesive flow in the rays while penetration of adhesive into the fibres and axial parenchyma was limited to only very few cells (1-3) near the bondline. PVAc penetration in the vessels could be observed up to a distance of approximately $200 \mu \mathrm{m}$ from the contact area between the wood surface and the adhesive for the control and the $10 \%$ PF-modified specimen, while in the case of pre-treatment with $25 \% \mathrm{PF}$ penetration depth was limited up to approximately $130 \mu \mathrm{m}$. Similar observations were made for the PRF adhesive in $25 \% \mathrm{PF}$ modified specimens presenting the lower penetration depth (approx. $160 \mu \mathrm{m}$ ). Control and $10 \%$ PF-modified samples showed comparable average penetration values of approximately 240 and $220 \mu \mathrm{m}$, respectively. Deposition of the PF resin into the cell wall and lumens as well as its hydrophobation effect (Furuno et al. 2004) affected adhesive penetration at $25 \% \mathrm{PF}$ concentration but resulted in significant lower adhesion only for PVAc.

\section{Conclusion}

The bonding performance of PF modified beech wood using PVAc and PRF adhesives was examined in this study. PRF adhesive causes higher shear strength than PVAc under both dry and wet condition. PF modified wood can be bonded satisfactorily with the two adhesive systems under dry conditions with the exception of wood modified with $25 \%$ PF solution and PVAc adhesive. PVAc adhesive should be avoided for gluing of PF modified wood to be used for exterior applications as water-soaking results in almost zero shear bond strength and very little wood failure. In exterior applications, the structural adhesive PRF and wood modified with high PF concentration was the best combination to achieve optimal bonding performance. For both adhesives, the penetration into the porous wood structure is the lowest at highest degree of PF modification.

Open Access This article is distributed under the terms of the Creative Commons Attribution License which permits any use, distribution, and reproduction in any medium, provided the original author(s) and the source are credited.

\section{References}

Boonstra MJ, Tjeerdsma BF, Groeneveld HAC (1998) Thermal modification of non-durable wood species. Part 1, The Plato technology: thermal modification of wood. International Research Group on Wood Preservation, Document no. IRG/WP 98-40123

Brandon R, Ibach RE, Frihart CR (2005) Effects of chemically modified wood on bond durability. In: Frihart CR (ed) Wood Adhesives 2005. Forest Products Research Society, San Diego, pp 111-114

European Standard (1992) EN 302-1: adhesives for load bearing timber structures - test methods-Part 1: determination of bond strength in longitudinal tensile shear

Frihart CR, Brandon R, Ibach RE (2004) Selectivity of bonding for modified wood. P Adhes Soc 27(1):329-331

Furuno T, Imamura Y, Kajita H (2004) The modification of wood by treatment with low molecular weight phenol-formaldehyde resin: a properties enhancement with neutralized phenolic-resin and resin penetration into wood cell walls. Wood Sci Technol 37:349-361

Gabrielli CP, Kamke FA (2010) Phenol-formaldehyde impregnation of densified wood for improved dimensional stability. Wood Sci Technol 44:95-104

Hill CAS (2006) Wood modification: chemical, thermal and other processes. Wiley, Chichester

Hunt CG, Brandon R, Ibach RE, Frihart CR (2007) What does bonding to modified wood tell us about adhesion? In: Proceedings 5th COST E34 international workshop: bonding of modified wood. Bled, Slovenia, pp 47-56

Kurt R, Mai C, Krause A, Militz H (2008) Hydroxymethylated resorcinol (HMR) priming agent for improved bondability of silicone modified wood glued with a polyvinyl acetate adhesive. Holz Roh Werkst 66:305-307

Ohmae K, Minato K, Nonmoto M (2002) The analysis of dimensional changes due to chemical treatments and water soaking for hinoki (Chamaecyparis obtusa) wood. Holzforschung 56:98-102

Rowell RM, Banks WB (1985) Water repellency and dimensional stability of wood. USDA General Technical Report FPL-50:1-24

Ryu JY, Takahashi M, Imamura Y, Sato T (1991) Biological resistance of phenol-resin treated wood. Mokuzai Gakkaishi 37(9):852-858

Ryu JY, Imamura Y, Takahashi M, Kajita H (1993) Effects of molecular weight and some other properties of resins on the biological resistance of phenolic resin treated wood. Mokuzai Gakkaishi 39(4):486-492

Sahin Kol H, Özbay G, Altun S (2009) Shear strength of heat-treated tali (Erythrophleum ivorense) and iroko (Chlorophora excelsa) woods, bonded with various adhesives. Biores 4(4):1545-1554

Sernek M, Boonstra M, Pizzi A, Despres A, Gérardin P (2008) Bonding performance of heat treated wood with structural adhesives. Holz Roh Werkst 66:173-180 
Stamm AJ (1959) The dimensional stability of wood. For Prod J 9(10):375-381

Stamm AJ, Seborg RM (1936) Resin treated plywood. Ind Eng Chem 31:897-902

van der Zee ME, Schipholt NL, Tjeerdsma BF, Brynildesn P, Mohoric I (2007) Glueability and paintability of furfurylated wood (Kebony). In: Hill CAS (ed) Proceedings Third European Conference on Wood Modification. Cardiff, UK, pp 231-234
Vick CB, Rowell RM (1990) Adhesive bonding of acetylated wood. Int J Adhes Adhes 10(4):263-272

Vick CB, Larsson PC, Mahlberg RL, Simonson R, Rowell RM (1993) Structural bonding of acetylated Scandinavian softwoods for exterior lumber laminates. Int J Adhes Adhes 13(3):139-149 